\title{
Design and evaluation of a dehumidifying plaster panel for passive architecture integration.
}

Diseño y evaluación de un panel deshumectador de yeso para su integración en la arquitectura pasiva.

Sofía Melero-Tur (Main Author) (Contact Autor)

Departamento de Construcción y Tecnología Arquitectónicas, Universidad Politécnica de Madrid, España.

Avda. Juan de Herrera, 4. 28040, Madrid (España).

+34913364246

sofia.mtur@upm.es

\section{Soledad García-Morales}

Departamento de Construcción y Tecnología Arquitectónicas, Universidad Politécnica de Madrid, España.

soledad.garcia@upm.es

\section{Abstract}

Buildings Indoor Air Quality requires a control in the Relative Humidity parameter. In passive architecture in humid climates relative humidity is even more important for human comfort and difficult to control. Therefore, nowadays, there is a research on dehumidifying systems. The present article shows an innovative dehumidifying panel composed of a plaster and Calcium Chloride salt. Laboratory tests are carried out to establish its viability as an indoor air moister regulator integrated in common plaster building interior coatings. There are two types of tests that have been carried out in two consecutive empirical phases: in the first phase, the tests of characterization of the Calcium Chloride as a desiccant are carried out; in a second phase, the dehumidifying panel as a whole is tested. Finally, both types of empirical tests show the efficiency and viability as an air moisture passive control system.

Keywords: Calcium Chloride; Plaster Panel; Moister Buffer; Relative Humidity; Passive Architecture.

\section{Introduction}

Dehumidification processes have been used in buildings since the first air conditioners. Mainly, there are active systems more related with engineering than architecture field, which need an energy source. Indoor air hygrothermal regulation is basic to ensure comfort in buildings. Furthermore, passive architecture is becoming more relevant in the worldwide building construction; for instance, the target established by the European Commission of Nearly Zero Energy Buildings for 2020 (Directive 2010/31/EU). In passive architecture, temperature and air moisture is regulated by no active mechanisms. That is why these "no-energy-consumption strategies" are a priority to reach comfort. Research on passive architecture and low consume mechanisms to reach comfort are the main aims for the future and present building construction. In the last years, more research groups and organizations working on this frame have been appeared; for instance, the PHDC project (Sánchez, 2012), focused on passive evaporative cooling systems. In the same way, Energy Efficiency and Green Building Certifications programs have recently appeared; as LEED, BREAM or PassivHaus standard (Hatt, 2012).

Research on passive regulation of temperature has been more studied (Givoni, 1994), but passive moisture regulation has been always more difficult to attempt. In the past few years, with the Nordtest project (Rode, 2005), it has been established a Moisture Buffer Value, MBV, for more common building materials. This standardized test has been used to analyze the moisture performance of different materials (Cerolini, 2009; Olivier, 2009; Collet, 2012; Dubois, 2014). In addition, it has been used to determine new test methods and numerical approaches (Janssen, 2009; Yoshino, 2009; Fazio, 2012; Zhang, 2012). However, when air moisture content is considerably high, moisture buffering capacity of building materials is insufficient

\section{Francisco Javier Neila-González}

Departamento de Construcción y Tecnología Arquitectónicas, Universidad Politécnica de Madrid, España

fjavier.neila@upm.es

\author{
Manuscript Code: 240 \\ Date of Reception/Acceptance: 08.08.2014/01.06/2015
}

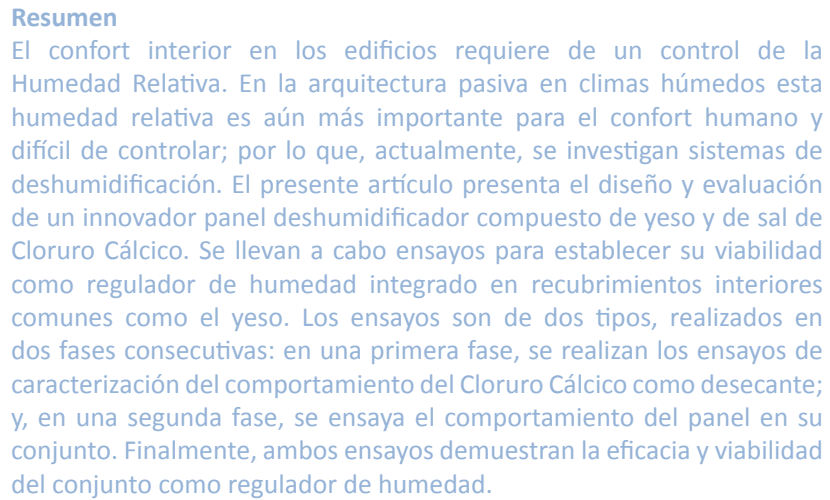

Palabras Claves: Cloruro Cálcico; Panel de Yeso; Regulador higrométrico; Humedad Relativa; Arquitectura Pasiva

for an appropriate moisture control and, consequently, there is indoor discomfort. In humid climates this is very common, temperature data are near comfort but humidity figures are always out of comfort ranges. ASHRAE Standard, international reference, establishes comfort humidity ratio $(\mathrm{w})$ limit at $12 \mathrm{~g}$ WATER/kg DRY AIR (ASHRAE Standard 55-2010). In Europe the Relative Humidity (RH) comfort range is from $20 \%$ to $70 \%$ for existing buildings and $25 \%$ to $60 \%$ for new buildings (UNE-EN 15251:2007).

The research in passive dehumidification drives us to test the viability of integration of passive desiccants in building construction materials. The challenge is to find the right combination of materials commonly used in architecture or in a domestic environment; not only because it is easier to acquire them but also it would be easier to integrate them in present building construction. On one hand, the plaster is one of the most used indoor finish building construction materials. It has a good moisture buffer capacity; its MBV is $0.61 \mathrm{~g} /$ $\mathrm{m} 2 \% \mathrm{RH}$ (Rode, 2005). There are materials with better MBV but in building construction there are not as common as plaster. On the other hand, the Calcium Chloride is a very common domestic desiccant used for wet rooms. There are several solid passive desiccants commonly used according to its purpose or destination, Calcium Chloride $(\mathrm{CaCl} 2)$ is one of the most efficient air moisture controllers. To trap air humidity, the salt $(\mathrm{CaCl} 2)$ changes its phase from solid to liquid, an exothermic phase change. In its liquid phase the dehumidifying capacity is even higher than in solid phase, but in this case it has been chosen the solid state, considered easier to handle with the use of plaster panels. The performance of the Calcium Chloride through a plaster panel has not been tested before.

The main aim of this research is to validate the viability and efficiency of the dehumidifying plaster panel. To reach this 
aim, the first stage consists on the characterization test for the Calcium Chloride dessicant as an air moisture trap; the second stage is the construction and monitoring of two prototypes of the dehumidifying plaster panel.

\section{Desiccant Properties}

Excess of indoor air moisture can promote the growth of allergenic or pathologic organisms that can cause different sort of human diseases (Berenguer, 1998). In dehumidifying processes water vapour is taken from the air by mainly four ways. The first one is through indoor ventilation with outside air, with lower humidity ratio (w); in the Spanish Building Construction Rules and Regulations (CTE-HS3, 2009) it is defined the ventilation flow rate according to different aspects of each location. The second one is condensing humidity ratio by cooling, commonly by means of cooled surfaces. The third one is condensing humidity by increasing air pressure, is the mechanism used by vapour pressure machines. The fourth one is using desiccants; they trap air moisture by vapour pressure differences. Some of these ones can be reused after a regeneration process. The present research is focused in the fourth way of dehumidification.

Desiccants are materials with great water vapour affinity and hygroscopic, comparatively with their weight and volume. Desiccants can be classified in liquid or solid and according to its adsorbent or absorbent properties. On one hand, the adsorbent desiccants are materials that attract and trap humidity without suffering chemical changes. They attract water molecules and retain them in their surface. Generally are solids as silica gel, zeolites, synthetic zeolites, alumina, activated carbon and synthetic polymers. On the other hand the absorbent desiccants are materials that attract and retain air moisture suffering a chemical change. The water molecules become part of the composition of the material. There are generally liquids; for instance, liquid solutions of lithium bromide, lithium chloride, Calcium Chloride, mixtures of these solutions and glycols.

\begin{tabular}{|c|c|}
\hline Comm & desiccants \\
\hline \multirow{6}{*}{ Solid Desiccants } & Silica gel \\
\hline & Molecular sieve \\
\hline & Zeolites \\
\hline & Alumina gel \\
\hline & Activated alumina \\
\hline & Activated carbon \\
\hline \multirow{3}{*}{ Solid Absorbents } & Calcium Chloride \\
\hline & Lithium Chloride \\
\hline & Phosphorus pentoxide \\
\hline \multirow{5}{*}{ Inorganic Liquid Absorbents } & Calcium Chloride \\
\hline & Lithium Chloride \\
\hline & Calcium Chloride \\
\hline & Potassium hydroxide \\
\hline & Sulfuric acid \\
\hline \multirow{4}{*}{ Organic Liquid Absorbent } & Ethylene glycol \\
\hline & Diethylene glycol \\
\hline & Triethylene glycol \\
\hline & Glycerol \\
\hline
\end{tabular}

Table 1 shows a classification of the most common used desiccants (Garg, 2000). In this table there are two types of liquid desiccants: hygroscopic salt solutions (inorganic) and glycols (organic). The dehumidifying efficiency is higher in an absorption process than in an adsorption one, due to the chemical change of state occurred in the first one. In addition, vapor pressures of liquid desiccants are lower than water at the same temperature; therefore, when they get in contact they can slurp the air water vapor more easily than the solids. The absorption process is exothermic, generates heat due to the chemical reaction in the change of state. This includes water latent heat absorbed by the desiccant and an additional absorbent heat that varies from 5 to $25 \%$ of the latent heat (ASHRAE, 1995).

However, from the desiccants listed on table 1, the more available and common in the market are silica gel, zeolites, sepiolites and Calcium Chloride. Calcium Chloride can be found as liquid or solid in table 1 . The solid one is commonly commercialized as a passive domestic dehumidifier. Liquid Calcium Chloride is commonly used with hybrid dehumidifying systems, with vapor compression systems. Its applications in engineering field are varied, from wheels to dehumidifying spray towers, walls and wet films.

\section{Properties of the Calcium Chloride}

Calcium Chloride is a hygroscopic salt formed by two chlorine atoms and one of calcium. Thus the formula is $\mathrm{CaCl} 2$ in its anhydrous form. Is a white substance, deliquescent and may be in solid or liquid form. The water vapor absorption capacity of the Calcium Chloride depends on Temperature ( $T$ ), Relative Humidity (RH) and on the amount of water the Calcium Chloride contains; that is to say, the type of hydrate. In figure 1 , in the section 4, it is represented the phase of Calcium Chloride according to the following hydrates $\mathrm{CaCl} 2 \cdot 6 \mathrm{H} 2 \mathrm{O}, \mathrm{CaCl} 2 \cdot 4 \mathrm{H} 2 \mathrm{O}$, $\mathrm{CaCl} 2 \cdot 2 \mathrm{H} 2 \mathrm{O}, \mathrm{CaCl} 2 \cdot \mathrm{H} 2 \mathrm{O}$, the properties of each one varies, these properties are detailed explained in the Calcium Chloride Handbook (Calcium Chloride handbook, 2003). Furthermore, according to the data obtained from manufactures, the desiccant maintains Relative Humidity range between $40 \%$ and $60 \%$ and removes excessive air moisture of rooms up to $35 \mathrm{~m} 3$ per each $450 \mathrm{~g}$ (quantity of a single package). These data have been confirmed with the figures of the empirical results of the present research.

In a psychrometric chart the desiccant behavior, according to temperature and humidity ratio variations, follows the Relative Humidity lines; that is to say, it is an iso-relative humidity behavior. The air moisture performance is defined by the humidity ratio (we) and Relative Humidity $(\mathrm{RH})$ following formulas, where Po stands for atmospheric pressure; $\mathrm{Pv}$ is vapor pressure; and Pvsat is saturated vapor pressure (Bedoya, 1997).

$\omega_{e}=0,622 \cdot \frac{p_{v}}{p_{0}-p_{v}}$

$\mathrm{RH}=100 \cdot \frac{\mathrm{p}_{\mathrm{v}}}{\mathrm{p}_{\text {vsat }}}$

Calcium Chloride is, in conclusion, one of the most available desiccants with good results as a domestic dehumidifier, commercialized in most of the countries and no toxic. In addition, because of its low vapor pressure as desiccant, is a good candidate for regeneration techniques; and with good properties of mass and heat transfer and low viscosity. Furthermore, the Calcium Chloride solutions do not crystallize within the operating limits, this can be considered as a positive 
data for the purpose of building integration and possible regeneration of the liquid obtained after the process, the $\mathrm{CaCl} 2$ contained in the solution can be regenerated.

\section{Plaster panel properties}

In the panel configuration, the gypsum has been elected as the second main material. On one hand, it is a very common building construction material; on the other hand, comparatively to other covering building construction materials, gypsum has a good moisture buffer behavior (Rode, 2005). Gypsum has not only a Moisture Buffer Value (MBV) appropriate for the purpose of the present research but also its hygroscopic inertia adds an important feature to consider in the dehumidifying panel. Hygroscopic inertia of building construction materials is quite well defined, Rode, 2005. However, the most important problem of these materials is their hysteric behaviour. Ramos and de Freitas (2010) studied numerically and experimentally the hygroscopic inertia of some covering materials and proposed the use of inertia classes for characterization of materials. They define the hygroscopic inertia as a relationship between the Relative Humidity variations of a room and the covering materials hygroscopicity.

What is most relevant for this research is that in the Moisture Buffering Capacity Evaluation results shown in Ramos and de Freitas research, the gypsum plaster has the highest moisture buffering capacity for a daily cycle and the highest moisture flux density coefficient. These two parameters are the most important for the plaster panel function in the dehumidifying process. The plaster panel works as a membrane that allows water vapor pass through it so it can be easily trapped by the desiccant enclosed behind the plaster panel. A material, as gypsum, that has a high moisture buffer capacity and a high moisture flux density is going to easily let the air moisture pass through it and regulates indoor air moisture content. In the prototypes designed for the present research, the gypsum panels have been manufactured in laboratory with two different hygroscopic properties, varying densities and porosities, to evaluate the influence of the described values on the whole dehumidifying process.

\section{Desiccant Characterization}

The characterization of the behavior of the desiccant in a controlled air moisture environment is relevant to determine, in a second stage, the dehumidifying efficiency through the plaster panel of the prototype. Two complementary laboratory tests have been performed. The first one consists in finding the equilibrium moisture of the desiccant and the second one aims to determine the rate of hydration.

\section{Equilibrium moisture content of the $\mathrm{CaCl} 2$}

This test consists on hydrating the desiccant till it reaches a humidity ratio where the environment Relative Humidity remains constant. Equilibrium moisture content is defined as the amount of moisture of a substance that remains in equilibrium with the environment at a given partial vapor pressure. The scientific reference of the equilibrium moisture content for Calcium Chloride in its liquid stage is nearby $32 \%$ at 20ㄷ (Hamdan, 2007). The test procedure consists on monitoring temperature and relative humidity inside a closed container during 21 days (container inner volume: $0.015 \mathrm{m3}$ ). Inside the container there are two trays with identical quantity of $\mathrm{CaCl} 2$ salt and water (total exposed surface: $0.075 \mathrm{~m} 2$ ). The water dissolves the salt while temperature inside the container rises up, consequence of the exothermic reaction of the change of phase from solid to liquid.

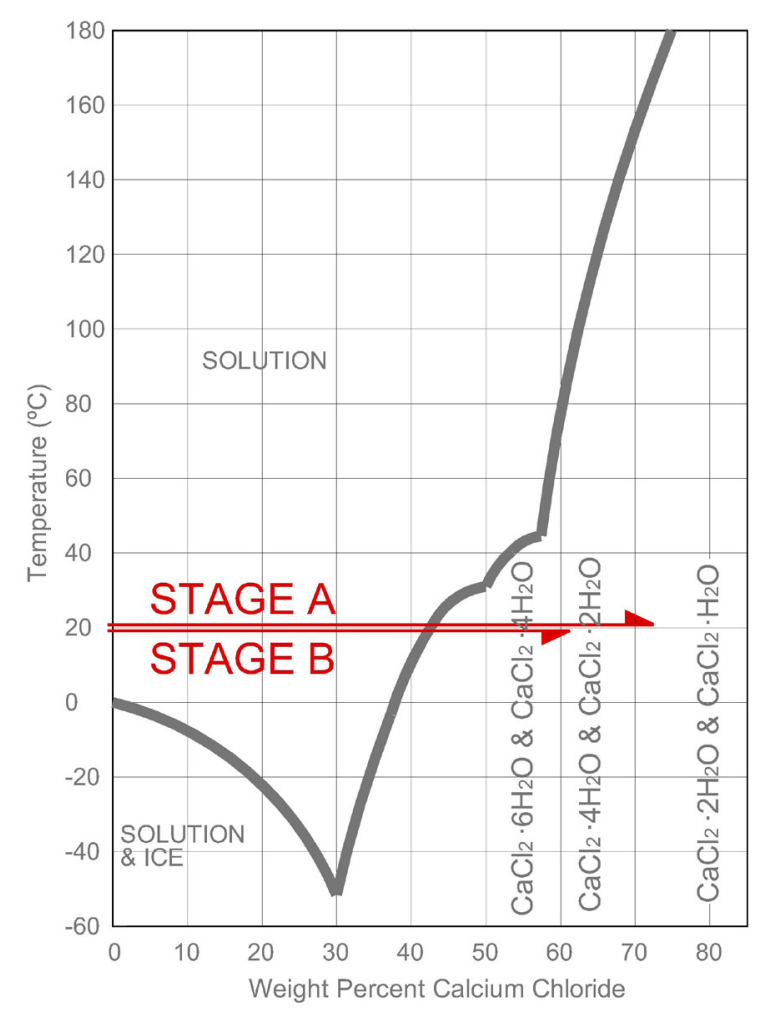

After 21 days, stage A of the experiment, in both trays the salt has crystallized in a homogeneous layer in the lower part of the trays and in top of it there is a Calcium Chloride and water solution. According to figure 1 where is represented the crystallization limit of different dissolutions of $\mathrm{CaCl} 2$ by a dark line, these results were predictable (Calcium Chloride handbook, 2003). Laboratory temperature was $20{ }^{\circ} \mathrm{C}$ and $\mathrm{CaCl} 2$ dissolution concentration was $72.4 \%$ by weight. On the stage $\mathrm{B}$ of the experiment, the crystallized Calcium Chloride is mixed with more water, lowering the dissolution concentration to $61.3 \%$ by weight.

\section{Results and interpretation}

\begin{tabular}{ccc}
\multicolumn{3}{l}{ Table 2. Hydration results (Self Elaboration, 2014). } \\
\hline RESULTS (STAGE A) & HYDRATION & Thickness (solid) \\
\hline TRAY 1 & $22.07 \%$ & $6.9 \mathrm{~mm}$ \\
\hline TRAY 2 & $21.62 \%$ & $10.05 \mathrm{~mm}$ \\
\hline AVERAGE & $\mathbf{2 1 . 8 5} \%$ & $\mathbf{8 . 4 8} \mathbf{~ m m}$ \\
\hline RESULTS (STAGE B) & HYDRATION & Thickness (solid) \\
\hline TRAY 1 & $-47.49 \%$ & $5.11 \mathrm{~mm}$ \\
\hline TRAY 2 & $\mathbf{- 5 5 . 4 5 \%}$ & $7.07 \mathrm{~mm}$ \\
\hline AVERAGE & $\mathbf{- 5 1 . 4 7 \%}$ & $\mathbf{6 . 0 9} \mathbf{~ m m}$
\end{tabular}

Hydratation $(\%)=\frac{W_{\text {final }}-W_{\text {dry(initial) }}}{W_{\text {dry(initial })}} \cdot 100$

To calculate the hydration percentages the formula used is the previous one (García, 1996). In which Wfinal stands for the final weight, Winitial stands for the weight in the beginning (when it is dry). In the collected data, not only the total weight in the trays has been registered but also the weight of crystallized Calcium Chloride and the quantity still in dissolution. Results obtained can be found in table 2 . In addition, from these results it can be interpreted that when there is a high quantity 
of $\mathrm{CaCl} 2$ in the dissolution it crystallizes and hydrates, stage A. In the second stage, stage B; the Calcium Chloride suffers a dehydration lowering the weight percentage. However the most interesting data for the main aim of the research are Temperature and Relative Humidity measures of the monitoring tests. There were obtained during the Stage A of the experiment, 21 days. Table 3 resumes the collected data where the desiccant behavior can be analyzed.

\begin{tabular}{lll}
\multicolumn{3}{l}{ Table 3. Hydration monitoring data (Font: personal compilation). } \\
\hline $\begin{array}{l}\text { Data Logger } \\
\text { (averages) }\end{array}$ & Container & Laboratory \\
\hline Relative Humidity & $36.00 \%$ & $43.60 \%$ \\
\hline Temperature & $17.40^{\circ} \mathrm{C}$ & $16.70{ }^{\circ} \mathrm{C}$ \\
\hline Specific humidity $\left(^{*}\right)$ & $4.48 \mathrm{~g} / \mathrm{kg}$ & $5.18 \mathrm{~g} / \mathrm{kg}$ \\
\hline Vapour pressure $\left(^{*}\right)$ & $0.72 \mathrm{kPa}$ & $0.83 \mathrm{kPa}$ \\
\hline
\end{tabular}

$\left({ }^{*}\right)$ calculated by given data

Figure 3. Behaviour of the desiccant during the Hydration test, relating Temperature and Specific Humidity variations (Self Elaboration, 2014).

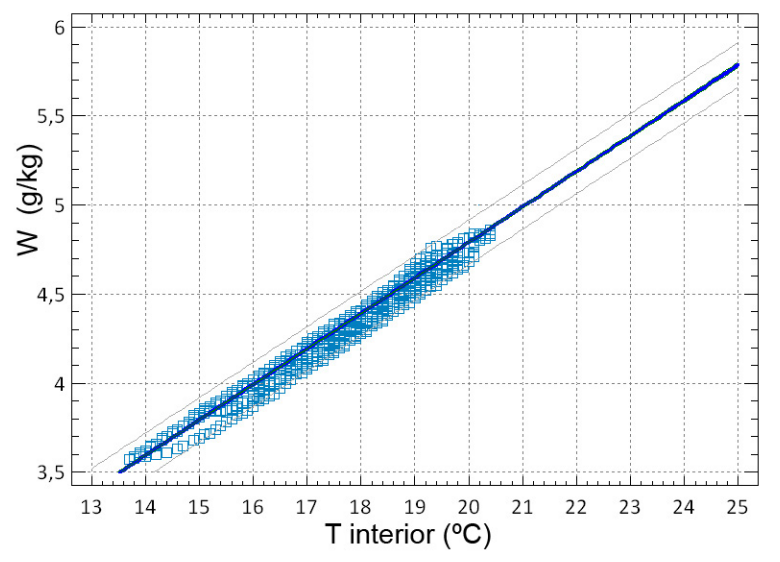

During the tests the desiccant has maintained Relative Humidity between $37.9 \%$ and $33.3 \%$, see graph of figure 2 . There is a symmetric behavior between Temperature and Relative Humidity, but it is difficult to analyze the air moisture variation during the test. In figure 3 , the graph of temperature and humidity ratio (We) shows better this variation. The desiccant behavior can be adjusted to a mathematical linear regression model with the following formula: We $=0.805639$ $+0.199253^{*}$ Tinside $(\mathrm{g} / \mathrm{kg})$. The desiccant is dehumidifying the environment maintaining a vapor pressure always below than the indoor air one, this certifies the effectiveness of the dehumidifying process. Analyzing these data in a psychrometric chart, the Relative Humidity range is between $30 \%$ and $40 \%$.

\section{Hydration rate of the $\mathrm{CaCl} 2$}

This test consists on determining the rate of hydration of the salt Calcium Chloride under a humid controlled environment (García, 1997). Temperature and Relative Humidity variations have been monitored inside a closed container (inner volume: $0.015 \mathrm{~m} 3$ ) during 3 stages of 21 days, 64 days in total. Inside the container there are two identical trays (total exposed surface: $0.075 \mathrm{~m} 2$ ) on top of a grid with identical quantity of Calcium chloride salt, see figure 4 . The $\mathrm{CaCl} 2$ salt has been oven-dried to constant weight before starting the experiment. A third tray with the humidifying saline solution (exposed surface: 0.059 $\mathrm{m} 2$ ), Sodium Chloride and water, is located in the lower part of the container. The humidifying salt solution will contribute to the environment a Relative Humidity between $75.3 \%$ and
$75.6 \%$ for a range of temperature between $25^{\circ} \mathrm{C}$ and $20^{\circ} \mathrm{C}$ (UNE-EN ISO 12571:2000).

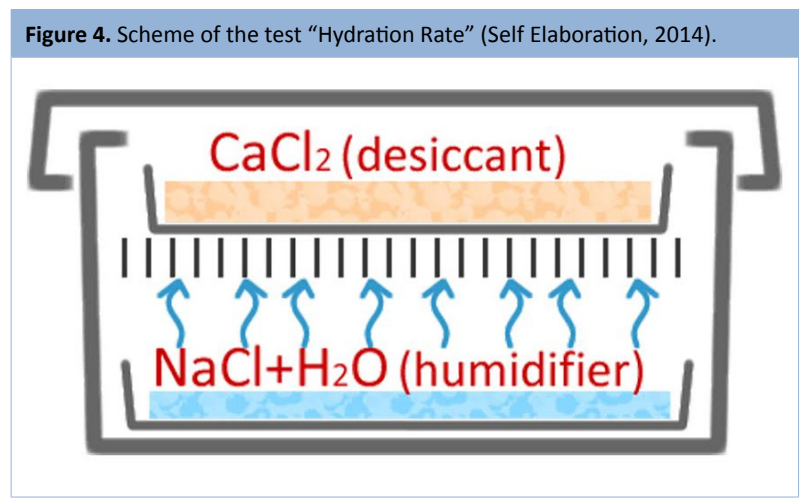

\section{Results and interpretation}

The collected data of weights for the hydration rate calculation was done at 21, 42 and 64 days giving the following results shown in the graph and data of figure 5 . The formula used for the percentages of the hydration data is the same as in the previous section 4.1. Data collected not only gives the hydration rate of the salt but also the rate of dissolution of the Calcium Chloride salt. From the graph in figure 5 can be seen how the hydration and dehydration lines cross at 42 days.

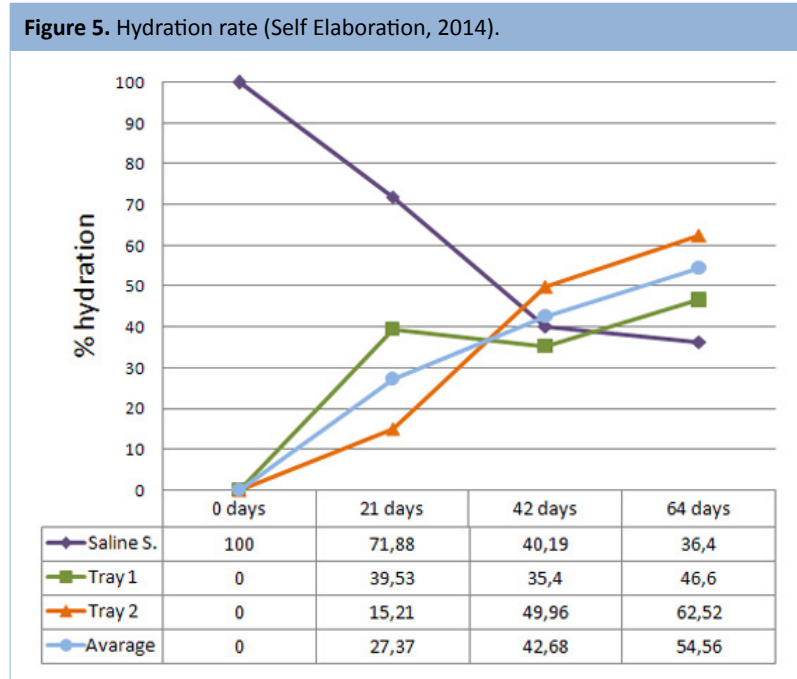

Table 4 shows the averages of the monitored data during the first stage (21 days). With these data, and knowing the contribution of the humidifying salt solution according to the Annex A in UNE-EN ISO 12571:2000, it is possible to calculate the contribution of the humidifying salt solution. And, consequently, the air moisture regulation is being carried by the salt Calcium Chloride. That is to say, for a Temperature of 16.9 -C (average) and Relative Humidity of $50.5 \%$, the contribution of Relative Humidity by the $\mathrm{NaCl}$ solution is of $75.67 \%$ inside the container and, consequently the salt $\mathrm{CaCl} 2$ regulates $25.17 \%$ of this Relative Humidity. 


\begin{tabular}{|c|c|c|}
\hline $\begin{array}{l}\text { Data } \\
\text { (averages) }\end{array}$ & Container & Laboratory \\
\hline Relative Humidity & $50.50 \%$ & $43.40 \%$ \\
\hline Temperature & $16.90^{\circ} \mathrm{C}$ & $16.60^{\circ} \mathrm{C}$ \\
\hline Specific humidity $\left(^{*}\right)$ & $6.08 \mathrm{~g} / \mathrm{kg}$ & $5.12 \mathrm{~g} / \mathrm{kg}$ \\
\hline Vapour pressure $\left({ }^{*}\right)$ & $0.97 \mathrm{kPa}$ & $0.82 \mathrm{kPa}$ \\
\hline
\end{tabular}

$\left.{ }^{*}\right)$ calculated by given data

Comparing the graphs of figures 2 and 6 , the dehumidifying capacity of the salt of Calcium Chloride is less than in dissolution (liquid phase). This can also be seen in the graph of figure 7, which represents the data in a graph of Temperature and humidity ratio (We). As in the same case as in the previous section, the desiccant behavior can be adjusted to a mathematical linear regression model with the following formula: $\mathrm{We}=0.53457+0.315234 *$ Tinside $(\mathrm{g} / \mathrm{kg})$. According to figure 6 , Relative Humidity range is between $46 \%$ and $54.5 \%$, these values are inside comfort ranges as explained in the introduction of the present article. This $\mathrm{RH}$ range is more easily understood in a psychrometric chart, see figure 7 , relating humidity ratio and temperature.

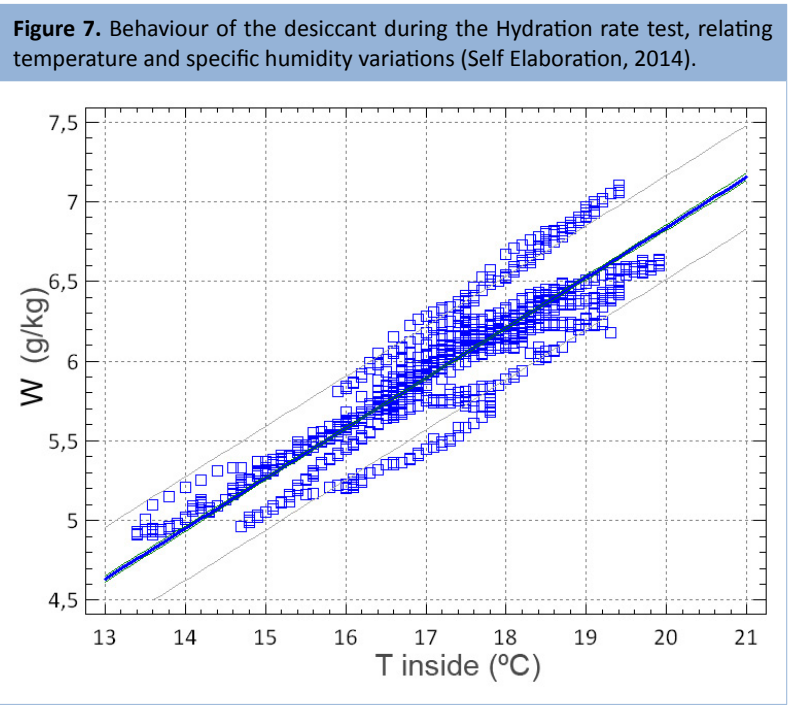

\section{Desiccant plaster panel performance}

After the characterization of the desiccant behavior in a controlled air moisture environment, a new test analyzes the dehumidifying efficiency of a plaster panel and Calcium Chloride combined together. For this purpose it is analyzed the $\mathrm{CaCl} 2$ moisture performance enclosed behind a plaster panel. In these experiments, the desiccant capacity of the Calcium Chloride salt through the plaster panel is tested, but also the influence of the plaster panel properties in the whole of the dehumidifying process. That is why two plaster panels with different properties have been specifically manufactured in laboratory for this new test.

The test consists on monitoring two box-prototypes with a controlled air moisture environment inside. Each box has one side with a different porosity plaster panel (exposed surface: $0.23 \mathrm{~m} 2$ ) and same amount of Calcium Chloride salt enclosed behind the panel, separated of the plaster panel by a polyethylene mesh (figure 8). Both boxes are identical in size, inner volume of each one is $0.125 \mathrm{~m} 3$, and identical materials, except for the plaster panel properties (characteristics of both plaster panels are registered in table 5). In both of them the same humidifying saline dissolution (Sodium Chloride and water) has been used. From the collected data, water vapor content in the panel can be calculated according to the quantity of water the panel can retain, knowing gypsum hygroscopicity is $1 \%$ (García, 1997). This calculated data is also registered in the following table 5 .

\begin{tabular}{llll}
\multicolumn{2}{l}{ Table 5. Plaster panels characteristics (Self Elaboration, 2014). } \\
\hline \multicolumn{2}{c}{ Plaster panel prototype 1} & \multicolumn{2}{c}{ Plaster panel prototype 2 } \\
\hline $\begin{array}{l}\text { ratio water/ } \\
\text { plaster }\end{array}$ & 0,54 & $\begin{array}{l}\text { ratio water/ } \\
\text { plaster }\end{array}$ & 0,89 \\
\hline density & $1,39 \mathrm{~g} / \mathrm{cm} 3$ & density & $0,79 \mathrm{~g} / \mathrm{cm} 3$ \\
\hline hygroscopicity & $1 \%\left(^{*}\right)$ & hygroscopicity & $1 \%\left(^{*}\right)$ \\
\hline Water vapor & $57,76 \mathrm{~g}$ & Water vapor & $34,58 \mathrm{~g}$ \\
\hline
\end{tabular}

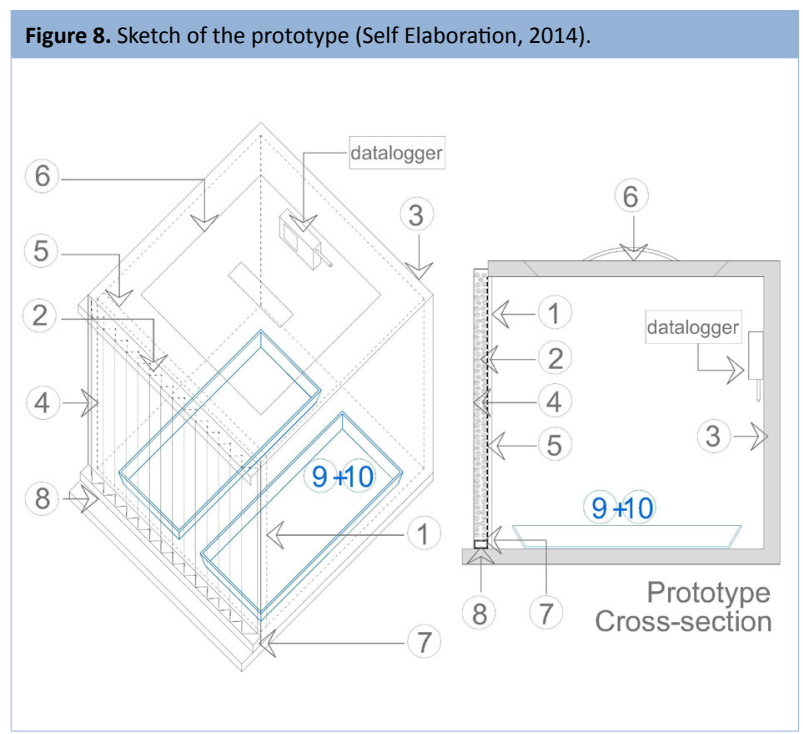

Figure 8 represents a sketch of the testing prototypes, the different numbers stands for: 1 . plaster panel; 2 . desiccant; 3 . extruded polystyrene (walls); 4. plastic film; 5. polyethylene mesh; 6. top (for register); 7. metallic grid; 8. collection channel. Inside, in the bottom part there are two trays with the saline solution (humidifiers) and in one of the walls is the datalogger that registers Temperature ( $\mathrm{T}, \stackrel{\circ}{\mathrm{o}} \mathrm{C})$ and Relative Humidity (R.H., \%).

\section{Results and interpretation}

The whole of the test lasted 105 days, collecting data every 21 days and controlling the amount of saline dissolution to guarantee the air moisture inside the prototype between $75 \%$ and $76 \%$ according to standards (UNE EN ISO 12571:2000). The test results of the dehydration of the saline solution (moisture provided to the environment); and the data of water vapor quantities in the plaster panel, evaporated by the humidifier and trapped by the desiccant are registered in table 6 . These results show that the prototype with the plaster panel of lower density (P1) is more permeable to water vapor than the one of higher one (P2).

As it has been shown in table 6 , the dehydration capacity of the Calcium Chloride salt through a plaster panel is effective. There is a direct relationship between the amount of water vapor absorbed by the desiccant and the density of the plaster panel; and, consequently its porosity. The density of plaster panel in prototype 2 is about half of prototype 1 and the amount of water vapor absorbed is about double. Comparing these data with the data obtained of Temperature and Relative Humidity from the dataloggers inside the prototypes, the 
Relative Humidity is regulated by the desiccant by lowering it about a 10\% in prototype 1 and about a 15\% in prototype 2 . Again, there is a direct relationship between the $\mathrm{RH}$ regulation capacity of the desiccant and the porosity of the plaster panel; in prototype 2 is $50 \%$ higher than in 1.

\begin{tabular}{lllll}
\multicolumn{5}{c}{ Table 6. Plaster panels characteristics (Self Elaboration, 2014). } \\
\hline $\begin{array}{l}\text { Dehydration } \\
\text { (saline sol.) }\end{array}$ & $\begin{array}{l}\mathrm{H} 2 \mathrm{O} \text { vapour } \\
\text { (evaporated) }\end{array}$ & $\begin{array}{l}\mathrm{H} 2 \mathrm{O} \text { vapor } \\
\text { (panel) }\end{array}$ & $\begin{array}{l}\mathrm{H} 2 \mathrm{O} \text { vapour } \\
\text { a b s o r b e d } \\
\text { (CaCl2) }\end{array}$ \\
\hline P.1 & $13,26 \%$ & $388,66 \mathrm{~g}$ & $57,76 \mathrm{~g}$ & $330,90 \mathrm{~g}$ \\
\hline P.2 & $25,34 \%$ & $636,33 \mathrm{~g}$ & $34,58 \mathrm{~g}$ & $601,75 \mathrm{~g}$ \\
\hline
\end{tabular}

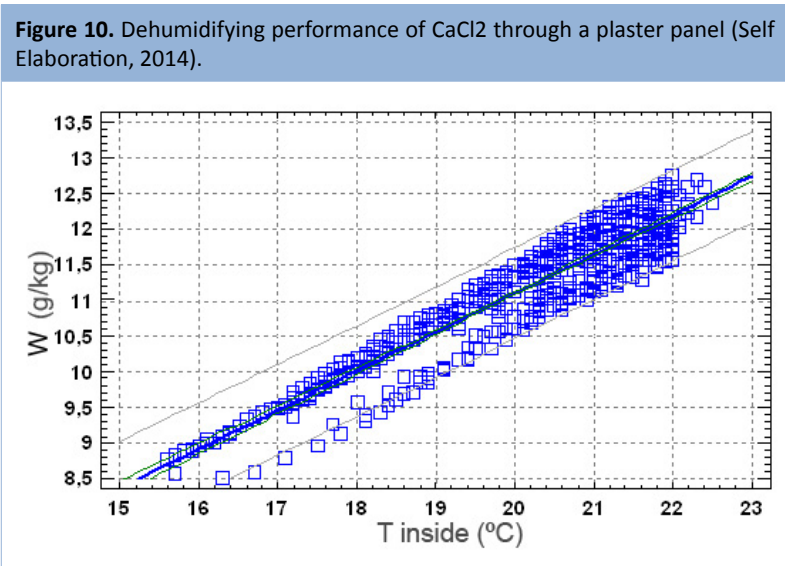

The dehumidifying behavior of prototype 2 is shown in figure 10. The symmetric behavior between Temperature and Relative Humidity although is not as clear as in previous tests of characterization, there is certain symmetry. In figure 10 the data is represented in a graph of Temperature and humidity ratio (We), the performance can be adjusted to a linear regression formula as in previous tests. The equation is: $W e=0.213689$ $+0.544227^{*}$ Tinternal. This behavior is according to a range of constant Relative Humidity lines. Furthermore, with the test of this two prototypes, it has been proved that the low vapor pressure the desiccant provides is enough to trap air moisture through the plaster panel. In other words, the Calcium Chloride salt can suck the inside air moisture through the plaster panel.

\section{Conclusions}

The main aim of the research was to test the efficiency of a dehumidifying plaster panel prototype, according to the air moisture control capacity of the Calcium Chloride salt. The research has two phases. In the first phase, the challenge was to demonstrate the $\mathrm{CaCl} 2$ salt capability of controlling indoor air moisture through a porous building construction material, a plaster panel, and how this porosity affects its moisture control efficiency. After proving the viability of the prototypes tested in this first phase, the second phase will consist in evaluating the performance of the deshumidifying plaster panel under humidification and dehumidification daily cycles. For this purpose it is being designed a specific test, similar to the standarized MBV test for building construction materials (Rode, 2007).

Results presented in this article demonstrate the viability of the proposal. Moreover, there are some detailed conclusions of the laboratory experiments that complement the main objective of the research. Firstly, the Calcium Chloride has a better air moisture regulation as liquid solution than as solid salt; but, on the contrary, it presents more difficulties to be integrated in architecture as a liquid than as a salt. Secondly, the salt Calcium Chloride changes phase from solid to liquid in a quite low speed, in the case of study of this research it is the order of $24 \mathrm{~g}$ per day in the prototype 2 tested; this fact gives the possibility of collecting this solution in an easy way to try to re-use it after. Thirdly, there is a direct relationship between the plaster panel density and air moisture flow through the pores of the panel; what is more, there is a direct relationship between the plaster density and the air moisture regulation. Finally, the present research represents the first step for a passive desiccant plaster panel integrated in conventional building construction coverings.

\section{Acknowledgments}

To Professors David Sanz-Arauz and Alfonso García-Santos for their support on this research. And to the Research Group ABIO-UPM, Technical University of Madrid, that has economically supported the laboratory tests. 
ANSI/ASHRAE Standard 55-2010. Thermal Environmental Conditions for Human Occupancy. (2010). Atlanta: American Society of Heating, Refrigerating and Air-Conditioning Engineers, Inc.

ASHRAE. (1995). Desiccant and absorption cooling. ASHRAE Technical data bulletin 11, No.2. Atlanta: American Society of Heating, Refrigerating and Air-Conditioning Engineers, Inc.

Bedoya, C. \& Neila, F.J. (1997). Técnicas arquitectónicas y constructivas de acondicionamiento ambiental. Madrid: Munilla-Lería.

Berenguer, M.J. (1998). Chapter 44, Calidad del aire interior. In Stellman, J.M. (Eds.), Enciclopedia de Salud y Seguridad en el Trabajo, 3rd spanish edition (pp. 28-44). Madrid Ministerio de trabajo y asuntos sociales. Subdirección General de Publicaciones.

Calcium Chloride handbook (2003). A guide to properties, forms, storage and handling. Michigan: The Dow Chemical Company.

Cerolini, S., D’Orazio, M., Di Perna, C. \& Stazi, A. (2009). Moisture buffering capacity of highly absorbing materials. Energy and Buildings, 41, 164-168.

Collet, F. \& Pretot, S. (2012). Experimental investigation of moisture buffering capacity of sprayed hemp concrete. Construction and Building Materials, 36, 58-65.

CTE DB-HS3 (2009). Código Técnico de la Edificación. Documento Básico HS3: Calidad del aire interior. Ministerio de Fomento del gobierno de España: Madrid, España.

Directive 2010/31/EU (2010). Directive on the Energy performance of buildings (recast). European Parliament and the Council of the European Union: The Member States.

Dubois, S., McGregor, F., Evrard, A., Heath, A. \& Lebeau, F. (2014) An inverse modelling approach to estimate the hygric parameters of clay-based masonry during a Moisture Buffer Value test. Building and Environment, 81, 192-203.

Fazio, P., Li Y. \& Rao, J. (2012). An investigation of moisture buffering performance of wood paneling at room level and its buffering effect on a test room. Building and Environment $42,205-216$.

García, S. (1996) Metodología de diagnóstico de humedades de capilaridad ascendente y condensación higroscópica en edificios históricos, PhD thesis. Escuela Técnica Superior de Arquitectura, Universidad Politécnica de Madrid [Thesis in Spanish]

Garg, H.P. \& Prakash, J. (2000). Solar Energy fundamentals and applications. New Delhi: Tata McGraw-Hill.

Givoni, B. (1994). Passive and low energy cooling of buildings. New York: Van Nostrand Reinhold.
Hamdan, H., Hill, C. A. S., Zaidon, A., Anwar, U. M. K. \& Latif, M. A. (2007). Equilibrium moisture content and volumetric changes of Gigantochloa Scortechinii. Malasia. Journal of Tropical Forest Science, 19 (1), 18-24.

Hatt, T., Saelzer, G., Hempel, R. \& Gerber, A. (2012). Alto confort interior con mínimo consumo energético a partir de la implementación del estándar "Passivhaus" en Chile. Revista de la Construcción, 12 (22), 123-134.

Janssen, H. \& Roels, S. (2009). Qualitative and quantitative assessment of interior moisture buffering by enclosures. Energy and Buildings, 41, 382-394.

McGregor, F., Heath, A., Shea, A. \& Lawrence, M. (2014). The moisture buffering capacity of unfired clay masonry. Building and Environment, 82, 599-607 (doi: 10.1016/j. buildenv.2014.09.027).

Olivier, M. \& Cordeiro, K. (2009). Moisture performance of building materials: From material characterization to building simulation using the Moisture Buffer Value concept. Building and Environment, 44, 388-401.

Ramos, N.M.M., Delgado, J.M.P.Q. \& de Freitas, V.P. (2010). Influence of finishing coatings on hygroscopic moisture buffering in building elements. Construction and Building Materials, 24, 2590-2597.

Rode, C., Peuhkuri, R., Time, B., Svennberg, K. \& Ojanen, T. (2007). Moisture Buffer Value of Building Materials. Journal of ASTM International, 4(5), (33-44). JAI100369. 10.1520/ STP45403S

Sánchez, J., Salmerón, J.M., Molina, J.L., Sánchez, F.J. \& Álvarez, S. (2012). PHDC: sistemas de enfriamiento evaporativo pasivos e híbridos para edificios - software de prediseño. Revista de la Construcción, 12 (22), 73-91.

UNE-EN 15251 (2007). Parámetros del ambiente interior a considerar para el diseño y la evaluación de la eficiencia energética de edificios incluyendo la calidad del aire interior, condiciones térmicas, iluminación y ruido. Asociación Española de Normalización y Certificación (AENOR): Madrid, España.

UNE-EN ISO 12571 (2000). Prestaciones higrotérmicas de los productos y materiales para edificios. Determinación de las propiedades de sorción higroscópica. Asociación Española de Normalización y Certificación (AENOR): Madrid, España.

Yoshino, H., Mitamura, T. \& Hasegawa, K. (2009). Moisture buffering and effect of ventilation rate and volume rate of hygrothermal materials in a single room under steady state exterior conditions. Building and Environment, 44 1418-1425.

Zhang, H., Yoshino, H. \& Hasegawa, K. (2012). Assessing the moisture buffering performance of hygroscopic material by using experimental method. Building and Environment, 48, 27-34. 


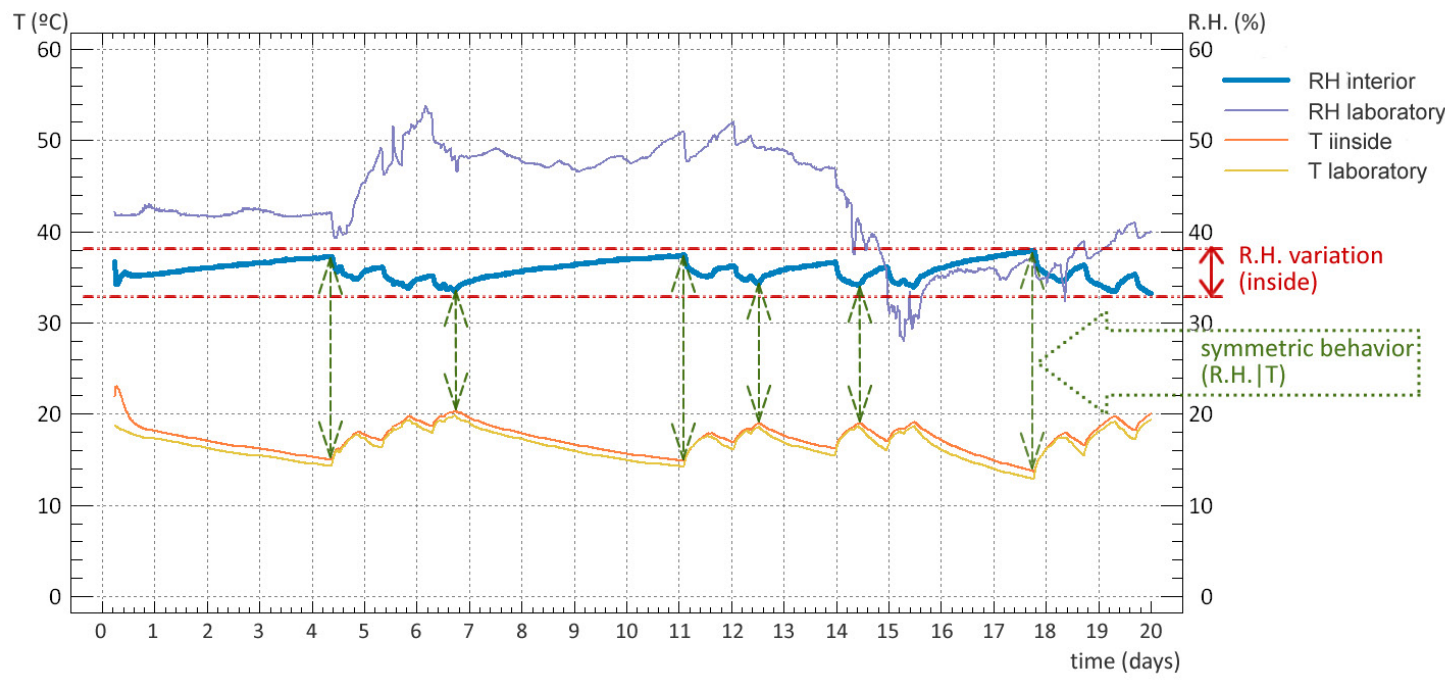

Figure 6. Graph of dehumidifying behaviour of salt Calcium Chloride during the Hydration Rate test (Self Elaboration, 2014).

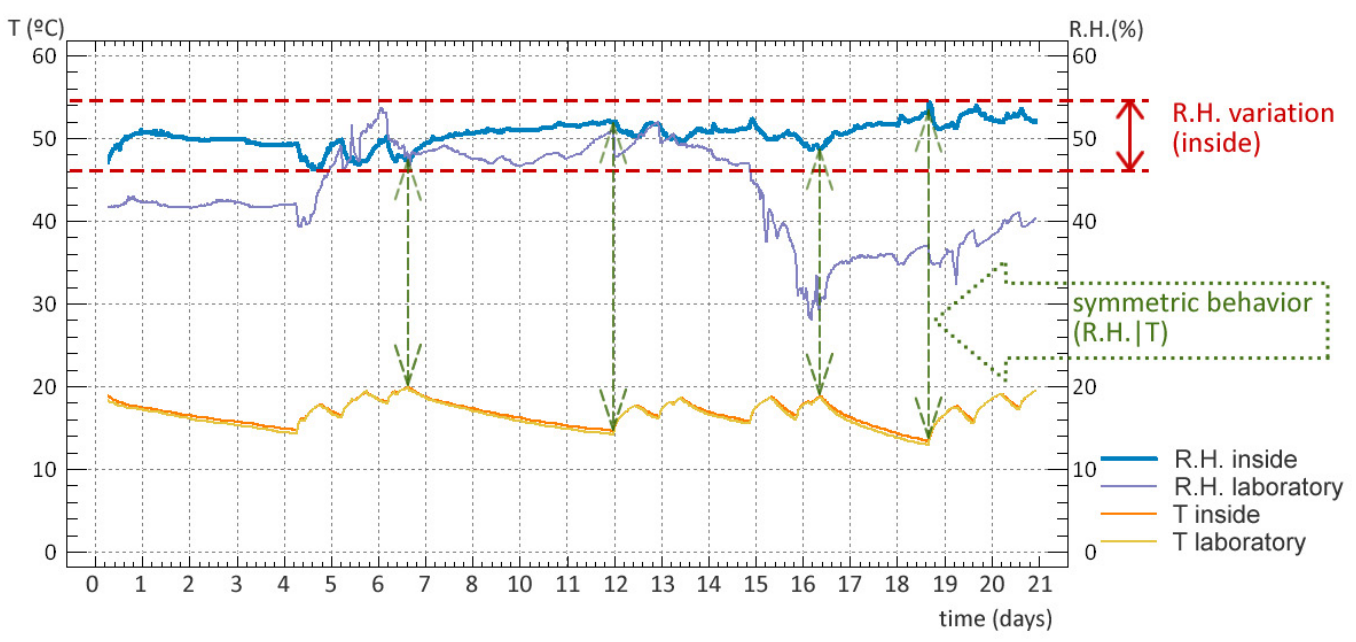

Figure 9. Graph of dehumidifying performance of salt Calcium Chloride through plaster panel -Prototype 2- (Self Elaboration, 2014)

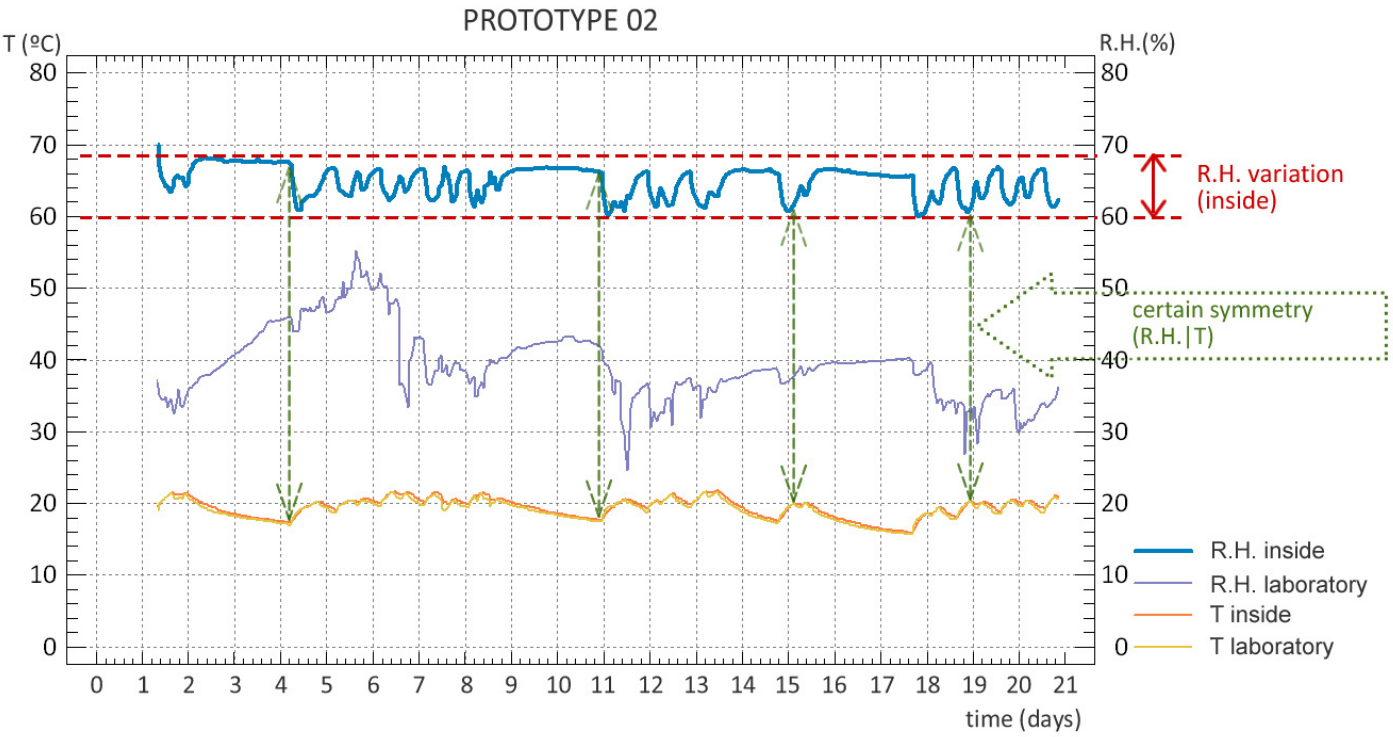

